\title{
Factive Presupposition in American Presidential War Speeches: Pragmatic perspective
}

\author{
الافتر اض الحقيقي في خطابات الحرب الرئاسية الامريكية: منظور تداولي
}

Eman Riyadh Adeeb(Instructor at University of Diyala-College of Education For Human Sciences- Linguistics )

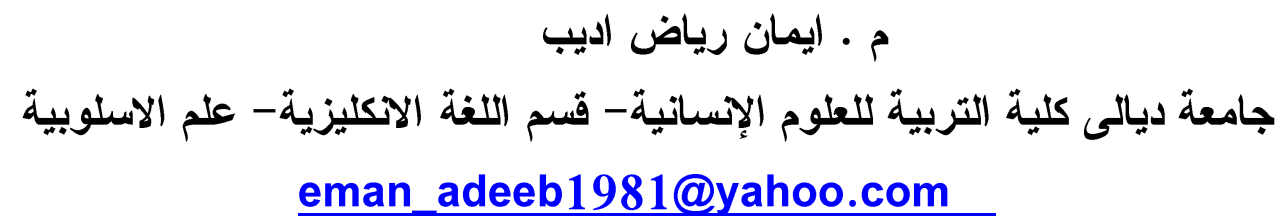

Atyaf Hasan Ibrahim(Assistant Instructor at University of DiyalaCollege of Education For Human Sciences- Linguistics)

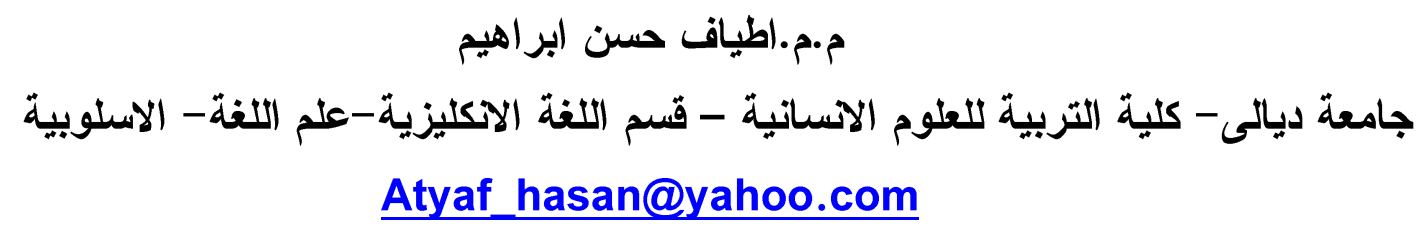

\begin{abstract}
This paper introduces our work on the pragmatic perspective of factive presupposition in American presidential war speeches. The major concern of this work is to highlight the significance of factuality in such selected speeches and its role in conveying certain messages .Pragmatics as a science has come to be applied to different practical domains depending on the view of the users, especially, the aims and purposes they want to achieve .Presupposition is one of the essential topics in pragmatics; it has a great deal of importance in various fields as in religion , law and politics. Thus, presuppositions is mainly and widely used and manipulated by many politicians. They are not allowed to make direct assertion or direct persuasion on their speeches . They tend to presuppose and use indirect constructions.
\end{abstract}

Because presupposition is a main topic, which is widely used covertly, the politicians used factive presupposition frequently and excessively, especially in declaring war. The study, in the first part deals with factive presupposition and a general review of this phenomenon with factuality and factive constructions .Part two deals with politics and language, then the last part which is dedicated to the practical implications and the analysis of factuality in the selected Americans presidential war speeches. 


\section{On Defining Presupposition}

The concept of "presupposition" is seen as an implicit meaning to what a speaker (writer) assumes as true, i.e., what a speaker pre-supposes as something true and known by a listener (or reader). Terminologically, presupposition is that term which refers to the conditions, the users of language assume, presuppose, state implicitly, covertly without claiming overtly. In fact, it is seen as the concept that deals with proposition that describe the conditions and the contexts of words, phrases and sentences . (Levinson , 2003 : 45 , Yule , $2010: 133$ )

Linguistically, Presupposition is those propositions which describe the conditions and the context of sentences ." $\mathrm{P}$ " presupposes "q" when the truth of "P" is required to make" q" a felicitous and a valid utterance .(Ibid)

Different linguists all over the world claim that languages provide various conventionalized carriers or containers of implicit covert meaning, i.e., it is the way and tool of linking explicit content to relevant aspects of background information. Leech (1989: 191) and Stalnaker (1995: 25) assert that in presupposition, there are two facets must be confirmed ;on one hand, presupposition pragmatically is the necessary conditions and assumptions made in writing, talking or conveying any utterance, distinct from that was actually asserted. On the other hand, presupposition might be identified into three base-conditions : speaker-based, hearer-based, and context-based. In the first slot, the speaker-based presupposition, the speaker or the writer takes something for granted ; in the hearer-based presupposition, we find the hearer, or reader takes something for granted ; and in the context-based presupposition, both speaker and listener make certain assumptions based on the context of the conversation. So , the concept presupposition is often treated as the relationship between two propositions, as in :

(a)Dora's cat is cute. (b)Dora has a cat.

In the examples above, there is (a) sentence with a proposition referred to as (p) and the "b" sentence has another proposition labeled as (a), which is easily presupposed and assumed by any listener. According to these assumptions, presupposition is described as the knowledge shared by the participants engaged in a communication act and event, which is the basis for the speaker to express himlherself to the listener because the speaker believes that the listener can understand what he or she says or wants to convey (Nauhardt $2009: 56$ ). 


\section{Presupposition : Different Perspectives}

Presupposition is regarded as one of the major topics of pragmatics that sheds light on the philosophy of logic. Historically, presupposition has a very long history in the study of pragmatics denoting to a special type of implicit information understood by the other participants in the action (Crystal 1991: 272)

Pragmatically, sentences with presupposition have been seen as utterances of individuals who are communicating through the language. As for pragmatic presupposition, generally speaking, we have three kinds of different points of view. First, pragmatic presupposition refers to the assumptions made by the speaker about the context in which languages communication happens. Second, pragmatic presupposition is regarded as a felicity condition or happiness condition (Aitchison , 1999 : 100). The condition which implements some speech acts. Finally, other linguists regard pragmatic presupposition as the mutual knowledge or common ground for communication as disunited before .

Presupposition arises a very crucial question whether it is something inherent in linguistic objects like words and sentences or it reflects properties of speakers. Semantically, presupposition is a semantic approach when it refers to what is entailed or pragmatic approach when it refers to what is assumed but not asserted in declarations, questioned in a question, or ordered in an imperative.

Furthermore, Davidson et al., (1972: 388) focus on the idea that there is no any contest between the semantic and pragmatic approaches of presupposition . They are basically related to each other but have different ideas. Generally speaking, any semantic presupposition of a proposition well expressed in a given context will without any doubt be a pragmatic presupposition of the participants in that under discussion context.

Fairdough (1995 : 107), Verschueren (1999 : 27)and Simon (2006 : 76)among other linguists, note that pragmatic presupposition is just persuasions about the context that must be attributed to the user of that context , hence, the participants should believe that context should fulfill the conditions used to give meaning to the utterance .

So, therefore, it is a term used to refer to propositions whose truth is taken for granted in the utterance of a linguistic expression, propositions without which the utterance cannot be evaluated. For example: it is said that the sentence "it's too bad that Obama lost the election" presupposes the 
proposition " Obama lost the election" while it is believed that Obama lost the election does not presuppose this(Green.1996:34)

To sum up, presuppositions are defined as those aspects of meaning that must be understood, presupposed and taken for granted for any piece of talk to make sense. Presupposition, as a result, is consistent and almost irrespective of context, though it has different types and facets (Davidson et al, 1972: 387; Jeffries, 1998: 152; Linton 2006: 157). The main types of presupposition classified as: existential, factive, lexical, structural, and nonfactive presupposition. This paper analyzes the impact of the factive presupposition in some selected American presidential war speeches.

\section{Factive Presupposition}

Presupposition is deeply interrelated with the use of a large number of words, phrases, and structures. So, accurately, the use of presupposition is derived from the words uttered in the context. Factive presupposition is one of the various types of this concept referring to the fact assumed or presupposed from the utterance. It is associated with the existence of certain verbs and constructions. These constructions have different linguistic forms (words, phrases, structures) which are ascribed as triggers of this type of presupposition, which can only become actual presupposition in context with speakers. These verbs indicate that something is a fact and true, all give rise to factive presupposition. By using any of these verbs in (1), the speaker or writer is presupposed to be committed to the truth of the entities.

(1) Everybody knows that Tom is gay ( >> Tom is gay)

- We regret telling him . (>>We told him)

- I was not Aware that she was married.(>> She was married)

Note: ( >>) means presuppose

These verbs, i.e., the verbs of facts and reality are regarded as lexical triggers. The presupposed information or utterance following such verbs "know, learn, realize, regret, see, apprehend, remember ... etc.", can be treated as a fact. These verbs are called (Factive verbs) because they presuppose the truth of the clauses complete them (Saeed 1997: 98). These verbs do not leave the proposition open as in:

(2) I believe he was overcharged. 
According to a number of linguists, presupposition has been regarded as a fact which is assumed to be true at the time of an utterance, but not mentioned , declared overtly. (Kiparsky, 1970: 262; Beaver, 2001: 5)

Moreover, talking about factive presupposition might define knowledge as justified true belief, for someone to know X, so it is important to regard $\mathrm{X}$ as something true. If we say "John knows $X^{\prime \prime}$, this presupposes implicitly the truth of $X$. It is very crucial to claim that the use of the factive verbs, implicitly framed the information given as truth rather than hypothesis.

Different constructions are phrased to presuppose the factual of the information given, as the following factive constructions (Yule, 2008:27).

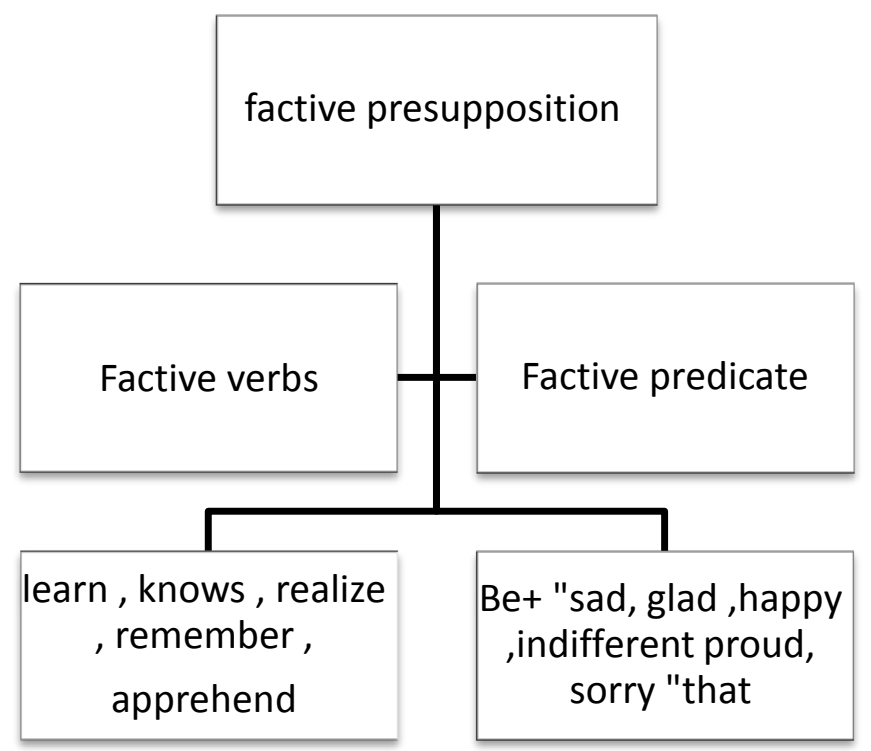

Figure (1) Factive presupposition (constructions)

In essence, Cattell (1987: 61 - 77) classifies verbs into three verbs:

1. Non-stance (factive): know, remember, ready, recognize, notice, regret, etc.

2. Response stance: deny, reiterate, accept, agree, confirm, admit, verify... etc.

3. Volunteered stance: believe, suppose, assume, claim, suspect ... etc.

Others as Hooper (1975: 91 ) state that such constructions might be referred to as strong factives or emotive factives namely referring to" regret , glad , and sorry ".So, in such domain , presuppositionality is associated 
with factive predicates followed by either strong clauses or weak ones as exemplified below :

The weak complement clauses are basically simplified in the following structures

John would regret

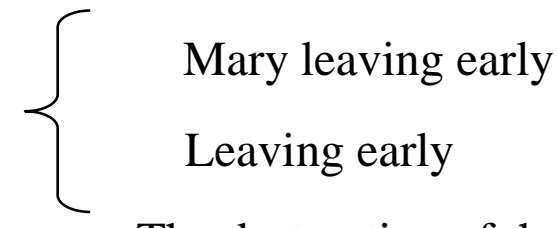

The destruction of the city

Strong clauses are expressed in the use of that-clauses and possessive-ing as in:

John would regret

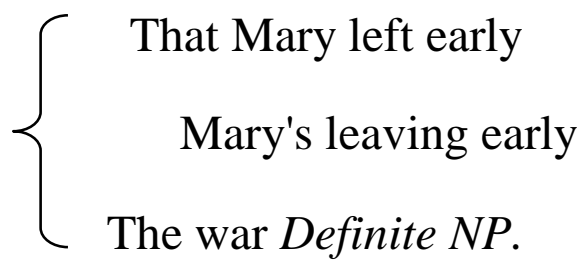

Hooper (1975:92) classifies the topic into various constructions and bounds; the use of factive verbs, adjectives and suitable adverbs.

\begin{tabular}{|l|l|}
\hline Assertive Semi- factive & Non- Assertive(True Factive) \\
\hline Find out & regret \\
realize & forget \\
know & amuse \\
remember & suffice \\
learn & bother \\
reveal & be interesting \\
notice & make sense \\
see & care \\
& be add \\
\hline
\end{tabular}

Diagram (1)

\section{Language and Politics}

Doubtlessly, the assumption that the way of understanding social and political speeches, problems and events begins with understanding the languages of the users of such utterances (Gunnarsson, 2009:5 cited in O'Barr, 1976: 433 )politics is regarded as the art of governing, i.e., assuring survival, by resorting to persuasion, suasion, manipulation, rather than the application of sheer arbitrary and brute force . (Grick, 1964: 126). As a 
point of interest, the language of politics is to some extent seen as a delicate and sophisticated instrument with potential as a multi-purpose one.

Bretton (1976: 432) states that politics is defined, as "an almost indefinite variety of things-not things, there is paradigms, but things-hazy, vague, relationships difficult to isolate and identify .... It means conducting irregularly what by non-political methods, or in a nonpolitical context, would be conducted with regularity.

Of the same tone, O'rwell (1950: 77) focuses on the decline of languages to political and economic factors. He goes further by stating that the decline of language must have political and economic reasons. Additionally, He points out that the influence of the political speech "politics" on the English language has resulted "vagueness and sheer incompetence ". Also, it causes the concrete to melt into abstract. In regard to the language of politics, it is sensible, as emphasized by many linguists, to present and held the enormous construction recommended in such Language. Political language, as Seidel (1985: 44) states, is a mutual interaction. Throughout history, politicians considered language as policies to be within the domain of their jurisdiction.

As it has been mentioned earlier in the first paragraph of this section that the political language is in fact a highly eclectic language variety.

Hence, it is not easily identifiable, sometimes it is emotive whereas on other occasions seems fact-oriented. Specific to our topic, generally speaking, in political speeches, speakers set more presuppositions, while hearers endeavor to settle those unfavorable presuppositions. In politics, the only "weapons" allowed are "words" and "arguments" to be more skillful and appropriate (Baily, 1976: 253). Finally, to sum up this section, Halliday et al., (1964: 89) argue that language is not realized as "the activity of people in situations; as linguistic events, which are manifested in a particular dialect and register."

\section{The Analytical Framework}

The main purpose of this section is to analyze and investigate the nature of factive presupposition and its responsibility in the expressions used to yield certain and specific communicative effects. The data selected are opted from three American presidential war speeches. Those war speeches were chosen haphazardly from different chronological orders. Speech (1) is Woodrow Wilson's war message, advising Congress to declare war on Germany; speech (2) Franklin D. Roosevelt's war message, asking 
Congress to declare war on Japan; speech (3) is the war announcement of president George Bush against Iraq.

\section{A. The Analysis of Speech ( 1)}

Presupposition is generally defined as a fact, which is assumed to be true at the time of speaking, but not mentioned overtly. Factivity as a phenomenon can be realized in many ways; here, we focus on factive presupposition in American presidential war speeches. In Wilson's war message; we perceive that there are many constructions deliberately used to advise the congress to declare war on Germany in 1917.

Thus, different concepts, items and constructions are intentionally used to represent factive presupposition in Wilson's speech:

1. The president mentioned different highly suggestive forceful verbs and constructions like" assure, certify, assert, ... etc. "with specific textual use of the modals which are often substantial to convey a variety of sense as obligation, assertion, necessity and compulsion as in:

\section{A) Highly suggestive assertive verbs:}

It would suffice to assert our neutral rights with arms.

B) Models suggestive of high degree of necessity are being utilized so as to indicate the nation's determination:-

- American ships have been sunk, American lives take... German submarine have been used against merchant shipping

C) Models of necessity and obligation "must, should..." are being used excessively to indicate the obligation of the decision as in:

-The world must be safe for democracy. Its peace must be planted upon the tested foundations of political liberty....

From the examples stated above, the president reviews the principles and values; therefore, he keeps on using highly suggestive verbs including the models and the assertive main verbs to indicate the firmness and exchangeability of their values.

2. The use of factive - mental activity verbs as "know, realize, understand, etc." Herein, the president mentioned the factive verbs to presuppose the truth of the events in his speech as in: 
- We are accepting this challenge of hostile purpose because we know that in such a government. Inasmuch the president tends to assume the decisive determination that the states are to be defended and that the war is inevitable, so the use of verbs such as enter, defend, fight,...etc. is to transmit the resoluteness to fight as in :

- Just because we fight without rancor... challenged us to defend our right and our honor... we enter this war only we are clearly forced unto it.

3- The verb" be" is being used frequently to denote firmness and resoluteness. The president mentioned the factual events of which he seems to be so sure by using the verb "be". Thus, however, accounts for his ongoing use of be + adjectives or complements, as in"

- It is a war against all nations.

- The precautions taken were meager and haphazard enough.

- It is impracticable.

- Our motive will not be revenge or the victorious assertion of the physical might of the nation... Which we are only a single champion.

As we do know that one of the inherent uses of "be" is the notion of "permanence". Therefore, the president keeps on repeating his statements interspersed with the verb "be" as in:

- The present German submarine warfare against commerce is a warfare against humankind.

Moreover, the use of the passive voice also might sometimes add the sense of persuasion and encouragement since the president attempts to legalize the attack on Germany and this is another kind of factive presupposition, which the president is taking on.

\section{B. The analysis of Speech( 2)}

In the same manner pursued in the first speech by the president Wilson, Roosevelt declared war on Japan asking the congress to give the permission. The president is stating factive presupposition in the form of various concepts and constructions as in:

1. The verb "be" is being used to suggest firmness that Roosevelt wants to assert. He insists on using the ongoing "be" verb, which denotes permanence. Interspersing his speech with the frequent use 
of "be" with different constructions and complements the president gave his speech.

- The United States was at peace with that nation...

In the statement above, the president attempts to convey that the United States is no longer in peace and this is a fact which cannot be ignored so he keeps on using and repeating the highly- suggestive verb "be" with a number of concepts and complements. To give legality to his attack, he uses the verb "be" in the past tense denoting that America WAS in peace but now they feel the danger of being insecure anymore.

2. The use of certain constructions and bounds denote intensely and intentionally the factivity of the phenomenon "presupposition". Roosevelt is reviewing the necessity and obligation of declaring war on Japan because of the factive events as in:

- The people of the United States have already formed their opinion and well understand the implications to the very life and safety of our nation.

Roosevelt, here, attempts to persuade the congress to wage war against Japan by using certain constructions as " already" in the previous sentence and the use of " at the fact " referring to that he has already get the approval and blessing of the civilians ,as in:

- There is no blinking at the fact that our people, our territory and our interests are in great danger.

The foregoing analysis of Roosevelt's speech denotes that he tries to persuade the congress to wage war against Japan by repeating the use of the verb "be" and the complements that came after entail that there is an inevitable decision to declare this war.

\section{The analysis of speech (3)}

In speech no. "3", we notice that the American president George Bush is announcing war against Iraq. In accordance with his speech, presupposition arises from the linguistic and syntactic constructions and bounds that he keeps on repeating them to get the consent of the United States congress. The devices he utilizes to convince the congress are:

1. The excessive use of the models and auxiliaries, which are used to denote the sense of high - degree of necessity and obligation depending on the bygone events as in:- 
- Our objectives are clear: Saddam Hussein's force will leave Kuwait. Here, Bush asserts the ability of his force and their objectives to oblige Saddam's forces to withdraw. Another example is:-

- Iraq will eventually comply with all relevant United Nations resolutions

The use of "will" in the above examples with the use of different verbs presupposes that the American forces are able to make the Iraqi forces fall back. However, "will" has the sense of futurism but it implies the idea of being sure and certain that they have the opportunity to make their enemy fall down depending on their preparations and tactics. "Will" in this context demonstrates the fact that Bush is both willing to interfere to drive the Iraqi force out of Kuwait and fully capable , as the president of the United States, of doing that, beside "will" is pronounced with primary stress to emphasize this very fact of potentiality and willing uses .

1. The use of the verb "Be" is to give a high degree of firmness and steadiness, Bush is relating it with various constructions to persuade the world in his attempts to wage attack on Iraq, as in:

- Tonight, America and the world are deeply grateful to them and to their families. (those in uniform)

He keeps on repeating the verb "be" followed by objectives of thankfulness to give legitimacy to his war and the deeds they committed, as in:

- We are successful ... and we will be ....

As we know that the use of the verb "be" strengthens the sense of factivity, so factivity, here, is associated deeply with the idea of "presuppositionality" with regard to all examples cited from Bush's war speech, there is a tendency to exaggerate the final results of this war against Saddam's regime by repeating this verb a sin:

\section{- Our objectives are clear.}

In fact the use of the verb Be with such adjectives is just an attempt to get the blessing and the approval of the coalition countries and the world to being the attack against Iraq presupposing the ability of these forces to prong any country.

2. The verbs of assertivity, high degrees of firmness and mental factivity such as: "believe, know, remain, assert, realize, remain ...etc." The president is amplifying his speech with these forceful verbs to give the 
sense of necessity, obligation and unavoidability of entering this war. He states this explicitly in :

- We now believe that only force will make him (Saddam) leave.

- He remained intransigent certain that time was on his side.

In these both examples, Bush is stating that they have the certainty that force and war are the only solution to make Iraq retreat.

3. The use of certain adverbs and adjectives, which give prominence to the use of presupposition. The adverbs or adjectives of recurrence which refer implicitly to the reasons behind any event furthermore presupposes the events happened. Similarly, in Bush's speech, true and factive presupposition is well established, as in the examples below:

- Now the 28 countries with forces have no choice but to drive Saddam from Kuwait by force.

- We will also destroy his chemical weapons facilities.

- Kuwait will once again be free.

- The world could wait no longer.

- Sanctions alone would not force Saddam from Kuwait.

- Saddam was warned over and over again to comply with the will of the United Nations.

In the aforementioned examples, the president is trying to assert the depletion of all attempts to bypass the war. He presupposes true bygone facts denoting the depletion of all peaceful choices. The over-valuation of the Iraqi regime danger drives the coalition forces to indulge in their war. Though they had been trying to steer clear of this war, but Bush mentions it explicitly by the use of "no", "again" "alone", "over and over" and "once" that they have no other choice and all gone in vain even the sanctions are not enough to make the Iraqi regime hold down. Bush presupposes that the coalition forces already tried to avoid any military intervention against Iraqi but all these solutions went in vain so he keeps on repeating those adverbs and adjectives to convey two messages; the first one is the fact that they exhausted all solutions; and the second one is the presupposition that they have the capability to make Iraqi regime withdraw. 


\section{Conclusions}

In this paper, the researchers have come up with a number of significant points, as cited in below:

1. Presupposition as a linguistic term is used to describe any kind of background assumption against which an action, event, utterance or even condition makes sense or is being rational.

2. Presupposition has a great deal of importance in political speeches ,especially War speeches so as to give legitimacy and validity to any attack against others and to persuade the world of their objectives .The politicians are not allowed to make direct assertion but to make indirect assertion via factive presupposition.

3. The highly use of suggestive forceful verbs like" assure, certify, assert ...etc." with specific textual use of the modals to convey a variety of sense as obligation, assertion, necessity and compulsion.

4. The use of certain adverbs and adjectives impart another feature to the war-declaration messages, which is totally associated with the existence of certain bygone events they refer to. The persistent use of these constituents presupposes the reasons and causes of waging such wars.

5. The use of the verb "Be", in this context, is to give a high degree of firmness and steadiness, all presidents' speeches are filled with the verb be with various constructions to persuade the world in their attempts to wage attack on other countries.

6. Passivization in war speeches sometimes adds more presuppositionality to the texture of the presidents' war in conveying the causes of such attacks.

\section{- Bibliography}

Aitchison, Jean (1999).Linguistics. London: Hodder Headline PIC.

Baily, F.G. (1976)."I-Speech in Orissa "In W. O' Barr, W. and O 'Barr Y. (ed.) (1976). Language and Politics. Mouton: The Hague. 
Beaver, D.I. (2001).Presupposition and Assertion. London: CSLI Publication.

Bretton, H.L. (1976)."Political Science, Language and Politics, "In W. O'Barr, W. and O' Barr Y. (ed.) (1976) Language and Politics. Mouton: The Hague.

Cattell, Ray. (1978) Language. Cambridge: Cambridge University Press.

Crystal, David. (1991) A Dictionary of Linguistics and Phonetics. Oxford: Blackwell.

Davidson, D. and Harman G. (ed.). (1972) Semantics and Natural Language. Dordrecht: Reidel.

Fairclough, Norman. (1995) Critical Discourse Analysis. London: Longman.

Green, Georgia M. (1996) Pragmatics and Natural language Understanding. United States: Lawren, Erlbqum Associates, Inc.

Grick, M. (1976)" Politics and Society "in W. O 'Barr, W. and O 'Barr Y. (ed.) (1976) Language and Politics. Mouton: The Hague.

Gunnarsson, J. (2009) Discourse Analysis. New York: Oxford press.

Halliday, M.A.K., Mc In tosh, A., and Stevens, P. (1964).The Linguistic Science and language Teaching. London: Longman.

Hooper, Joan.(1975).In Syntax and Semantics .New York: Academic Press.

Jeffries, Lesley (1998).Meaning in English :An Introduction to Language Study .London: MacMillan.

Kiparsky, P.(1970).Semantic Rules in Grammar . The Nordic languages and Modern Linguistics. London: MacMillan.

Leech, G.(1989).The Principles of Pragmatics. New York: Longman Inc.

Levinson, Stephen.(2003).Pragmatics. Cambridge :Cambridge university Press.

Linton ,Connor.(2006)An introduction to Language and Linguistics. New York :Oxford press. 
Nauhardt, Andreas.(2009).Logic :Sentence Relations and Truths .Oxford: Blackwell

O 'Barr, W. and O' Barr Y.(ed.) (1976)Language and Politics. Mouton :The Hague.

O' rwell, G.(1950)"Politics and The English Language ", In Shooting an Elephant $5^{\text {th }}$ (ed.) .New York: Harcourt Brace and Company.

Saeed ,John I.(1997) Semantics. Oxford:Blackwell

Seidel, G.(1985)"Political Discourse Analysis ." In Teun A. Van Dijk (ed.)Handbook of Discourse :Discourse Analysis in Society .London: Academic press.

Simon ,Mandy.(2006)Presupposition without Common Ground. Milano: Carnegie Mellon University.

Stalnaker , R.C.(1995)"Assertion "In Syntax and Semantics.Vol.9:Pragmatics,pp.315-333.

Ver schueren, Jef. (1999) Understanding Pragmatics .New York: Oxford University Press.

Yule ,George. (2010).The Study of Language . Cambridge :Cambridge university Press. (2008).Pragmatics. Cambridge :Cambridge university Press.

\section{Internet Web sites :}

WWW.Infoplease.com

WWW.historyplace.com 


\section{Appendices}

\section{Appendix (1)}

\section{Woodrow Wilson's War Message, Advising Congress to Declare War on Germany}

\section{Given on Monday, April 2, $1917^{1}$}

\section{Gentlemen of the Congress:}

I have called the Congress into extraordinary session because there are serious, very serious, choices of policy to be made, and made immediately, which it was neither right nor constitutionally permissible that I should assume the responsibility of making.

On the third of February last I officially laid before you the extraordinary announcement of the Imperial German Government that on and after the first day of February it was its purpose to put aside all restraints of law or of humanity and use its submarines to sink every vessel that sought to approach either the ports of Great Britain and Ireland or the western coasts of Europe or any of the ports controlled by the enemies of Germany within the Mediterranean. That had seemed to be the object of the German submarine warfare earlier in the war, but since April of last year the Imperial Government had somewhat restrained the commanders of its undersea craft in conformity with its promise then given to us that passenger boats should not be sunk and that due warning would be given to all other vessels which its submarines might seek to destroy when no resistance was offered or escape attempted, and care taken that their crews were given at least a fair chance to save their lives in their open boats. The precautions taken were meager and haphazard enough, as was proved in distressing instance after instance in the progress of the cruel and unmanly business, but a certain degree of restraint was observed. The new policy has swept every restriction aside. Vessels of every kind, whatever their flag, their character, their cargo, their destination, their errand, have been ruthlessly sent to the bottom: without warning and without thought of help or mercy for those on board, the vessels of friendly neutrals along with those of belligerents. Even hospital ships and ships carrying relief to the sorely bereaved and stricken people of Belgium, though the latter were provided with safe conduct through the proscribed areas by the German Government itself and were distinguished by unmistakable marks of identity, have been sunk with the same reckless lack of compassion or of principle.

I was for a little while unable to believe that such things would in fact be done by any government that had hitherto subscribed to the humane practices of civilized nations. International law had its origin in the attempt to set up some law which would be respected and observed upon the seas, where no nation had right of dominion and where lay the free highways of the world. By painful stage after stage has that law been built up, with meager enough results, indeed, after all was accomplished, but always with a clear view, at least, of what the heart and conscience of mankind demanded. This minimum of right the German Government has swept aside under the plea of retaliation and necessity and because it had no weapons which it could use at sea except these which it is impossible to employ as it is employing them without throwing to the winds all scruples of humanity or of respect for the understandings that were supposed to 
underlie the intercourse of the world. I am not now thinking of the loss of property involved, immense and serious as that is, but only of the wanton and wholesale destruction of the lives of noncombatants, men, women, and children, engaged in pursuits which have always, even in the darkest periods of modern history, been deemed innocent and legitimate. Property can be paid for; the lives of peaceful and innocent people cannot be. The present German submarine warfare against commerce is a warfare against mankind.

It is a war against all nations. American ships have been sunk, American lives taken, in ways which it has stirred us very deeply to learn of, but the ships and people of other neutral and friendly nations have been sunk and overwhelmed in the waters in the same way. There has been no discrimination. The challenge is to all mankind. Each nation must decide for itself how it will meet it. The choice we make for ourselves must be made with a moderation of counsel and a temperateness of judgment befitting our character and our motives as a nation. We must put excited feeling away. Our motive will not be revenge or the victorious assertion of the physical might of the nation, but only the vindication of right, of human right, of which we are only a single champion.

When I addressed the Congress on the twenty-sixth of February last I thought that it would suffice to assert our neutral rights with arms, our right to use the seas against unlawful interference, our right to keep our people safe against unlawful violence. But armed neutrality, it now appears, is impracticable. Because submarines are in effect outlaws when used as the German submarines have been used against merchant shipping, it is impossible to defend ships against their attacks as the law of nations has assumed that merchantmen would defend themselves against privateers or cruisers, visible craft giving chase upon the open sea. It is common prudence in such circumstances, grim necessity indeed, to endeavor to destroy them before they have shown their own intention. They must be dealt with upon sight, if dealt with at all. The German Government denies the right of neutrals to use arms at all within the areas of the sea which it has proscribed, even in the defense of rights which no modern publicist has ever before questioned their right to defend. The intimation is conveyed that the armed guards which we have placed on our merchant ships will be treated as beyond the pale of law and subject to be dealt with as pirates would be. Armed neutrality is ineffectual enough at best; in such circumstances and in the face of such pretensions it is worse than ineffectual: it is likely only to produce what it was meant to prevent; it is practically certain to draw us into the war without either the rights or the effectiveness of belligerents. There is one choice we cannot make, we are incapable of making: we will not choose the path of submission and suffer the most sacred rights of our Nation and our people to be ignored or violated. The wrongs against which we now array ourselves are no common wrongs; they cut to the very roots of human life.

With a profound sense of the solemn and even tragical character of the step I am taking and of the grave responsibilities which it involves, but in unhesitating obedience to what I deem my constitutional duty, I advise that the Congress declare the recent course of the Imperial German Government to be in fact nothing less than war against the government and people of the United States; that it formally accept the status of belligerent which has thus been thrust upon it, and that it take immediate steps not only to put the country in a more thorough state of defense but also to exert all its power and employ all its resources to bring the Government of the German Empire to terms and end the war. 
What this will involve is clear. It will involve the utmost practicable cooperation in counsel and action with the governments now at war with Germany, and, as incident to that, the extension to those governments of the most liberal financial credit, in order that our resources may so far as possible be added to theirs. It will involve the organization and mobilization of all the material resources of the country to supply the materials of war and serve the incidental needs of the Nation in the most abundant and yet the most economical and efficient way possible. It will involve the immediate full equipment of the navy in all respects but particularly in supplying it with the best means of dealing with the enemy's submarines. It will involve the immediate addition to the armed forces of the United States already provided for by law in case of war at least five hundred thousand men, who should, in my opinion, be chosen upon the principle of universal liability to service, and also the authorization of subsequent additional increments of equal force so soon as they may be needed and can be handled in training. It will involve also, of course, the granting of adequate credits to the Government, sustained, I hope, so far as they can equitably be sustained by the present generation, by well conceived taxation. I say sustained so far as may be equitable by taxation because it seems to me that it would be most unwise to base the credits which will now be necessary entirely on money borrowed. It is our duty, I most respectfully urge, to protect our people so far as we may against the very serious hardships and evils which would be likely to arise out of the inflation which would be produced by vast loans.

In carrying out the measures by which these things are to be accomplished we should keep constantly in mind the wisdom of interfering as little as possible in our own preparation and in the equipment of our own military forces with the duty-for it will be a very practical duty - of supplying the nations already at war with Germany with the materials which they can obtain only from us or by our assistance. They are in the field and we should help them in every way to be effective there.

I shall take the liberty of suggesting, through the several executive departments of the Government, for the consideration of your committees, measures for the accomplishment of the several objects I have mentioned. I hope that it will be your pleasure to deal with them as having been framed after very careful thought by the branch of the Government upon which the responsibility of conducting the war and safeguarding the Nation will most directly fall.

While we do these things, these deeply momentous things, let us be very clear, and make very clear to all the world what our motives and our objects are. My own thought has not been driven from its habitual and normal course by the unhappy events of the last two months, and I do not believe that the thought of the Nation has been altered or clouded by them. I have exactly the same things in mind now that I had in mind when I addressed the Senate on the twenty-second of January last, the same that I had in mind when I addressed the Congress on the third of February and on the twenty-sixth of February. Our object now, as then, is to vindicate the principles of peace and justice in the life of the world as against selfish and autocratic power and to set up amongst the really free and self governed peoples of the world such a concert of purpose and of action as will henceforth insure the observance of those principles. Neutrality is no longer feasible or desirable where the peace of the world is involved and the freedom of its peoples, and the menace to that peace and freedom lies in the existence of autocratic governments backed by organized force which is controlled wholly by their will, not by the will of their people. We have seen the last of neutrality in such circumstances. We 
are at the beginning of an age in which it will be insisted that the same standards of conduct and of responsibility for wrong done shall be observed among nations and their governments that are observed among the individual citizens of civilized states.

We have no quarrel with the German people. We have no feeling towards them but one of sympathy and friendship. It was not upon their impulse that their government acted in entering this war. It was not with their previous knowledge or approval. It was a war determined upon as wars used to be determined upon in the old, unhappy days when peoples were nowhere consulted by their rulers and wars were provoked and waged in the interest of dynasties or of little groups of ambitious men who were accustomed to use their fellow men as pawns and tools.

Self-governed nations do not fill their neighbor states with spies or set the course of intrigue to bring about some critical posture of affairs which will give them an opportunity to strike and make conquest. Such designs can be successfully worked out only under cover and where no one has the right to ask questions. Cunningly contrived plans of deception or aggression, carried, it may be, from generation to generation, can be worked out and kept from the light only within the privacy of courts or behind the carefully guarded confidences of a narrow and privileged class. They are happily impossible where public opinion commands and insists upon full information concerning all the nation's affairs.

A steadfast concert for peace can never be maintained except by a partnership of democratic nations. No autocratic government could be trusted to keep faith within it or observe its covenants. It must be a league of honor, a partnership of opinion. Intrigue would eat its vitals away; the plottings of inner circles who could plan what they would and render account to no one would be a corruption seated at its very heart. Only free peoples can hold their purpose and their honor steady to a common end and prefer the interests of mankind to any narrow interest of their own.

Does not every American feel that assurance has been added to our hope for the future peace of the world by the wonderful and heartening things that have been happening within the last few weeks in Russia? Russia was known by those who knew it best to have been always in fact democratic at heart, in all the vital habits of her thought, in all the intimate relationships of her people that spoke their natural instinct, their habitual attitude towards life. The autocracy that crowned the summit of her political structure, long as it had stood and terrible as was the reality of its power, was not in fact Russian in origin, character, or purpose; and now it has been shaken off and the great, generous Russian people have been added in all their naive majesty and might to the forces that are fighting for freedom in the world, for justice, and for peace. Here is a fit partner for a League of Honor.

One of the things that has served to convince us that the Prussian autocracy was not and could never be our friend is that from the very outset of the present war it has filled our unsuspecting communities and even our offices of government with spies and set criminal intrigues everywhere afoot against our national unity of counsel, our peace within and without, our industries and our commerce. Indeed it is now evident that its spies were here even before the war began; and it is unhappily not a matter of conjecture but a fact proved in our courts of justice that the intrigues which have more than once come perilously near to disturbing the peace and dislocating the industries of the 
country have been carried on at the instigation, with the support, and even under the personal direction of official agents of the Imperial Government accredited to the Government of the United States. Even in checking these things and trying to extirpate them we have sought to put the most generous interpretation possible upon them because we knew that their source lay, not in any hostile feeling or purpose of the German people towards us (who were, no doubt, as ignorant of them as we ourselves were), but only in the selfish designs of a Government that did what it pleased and told its people nothing. But they have played their part in serving to convince us at last that that Government entertains no real friendship for us and means to act against our peace and security at its convenience. That it means to stir up enemies against us at our very doors the intercepted note to the German Minister at Mexico City is eloquent evidence.

We are accepting this challenge of hostile purpose because we know that in such a Government, following such methods, we can never have a friend; and that in the presence of its organized power, always lying in wait to accomplish we know not what purpose, there can be no assured security for the democratic Governments of the world. We are now about to accept gauge of battle with this natural foe to liberty and shall, if necessary, spend the whole force of the nation to check and nullify its pretensions and its power. We are glad, now that we see the facts with no veil of false pretense about them, to fight thus for the ultimate peace of the world and for the liberation of its peoples, the German peoples included: for the rights of nations great and small and the privilege of men everywhere to choose their way of life and of obedience. The world must be made safe for democracy. Its peace must be planted upon the tested foundations of political liberty. We have no selfish ends to serve. We desire no conquest, no dominion. We seek no indemnities for ourselves, no material compensation for the sacrifices we shall freely make. We are but one of the champions of the rights of mankind. We shall be satisfied when those rights have been made as secure as the faith and the freedom of nations can make them.

Just because we fight without rancor and without selfish object, seeking nothing for ourselves but what we shall wish to share with all free peoples, we shall, I feel confident, conduct our operations as belligerents without passion and ourselves observe with proud punctilio the principles of right and of fair play we profess to be fighting for.

I have said nothing of the Governments allied with the Imperial Government of Germany because they have not made war upon us or challenged us to defend our right and our honor. The Austro-Hungarian Government has, indeed, avowed its unqualified endorsement and acceptance of the reckless and lawless submarine warfare adopted now without disguise by the Imperial German Government, and it has therefore not been possible for this Government to receive Count Tarnowski, the Ambassador recently accredited to this Government by the Imperial and Royal Government of Austria-Hungary; but that Government has not actually engaged in warfare against citizens of the United States on the seas, and I take the liberty, for the present at least, of postponing a discussion of our relations with the authorities at Vienna. We enter this war only where we are clearly forced into it because there are no other means of defending our rights.

It will be all the easier for us to conduct ourselves as belligerents in a high spirit of right and fairness because we act without animus, not in enmity towards a people or with the desire to bring any injury or disadvantage upon them, but only in armed opposition to 
an irresponsible government which has thrown aside all considerations of humanity and of right and is running amuck. We are, let me say again, the sincere friends of the German people, and shall desire nothing so much as the early reestablishment of intimate relations of mutual advantage between us,- - however hard it may be for them, for the time being, to believe that this is spoken from our hearts. We have borne with their present Government through all these bitter months because of that friendship,exercising a patience and forbearance which would otherwise have been impossible. We shall, happily, still have an opportunity to prove that friendship in our daily attitude and actions towards the millions of men and women of German birth and native sympathy who live amongst us and share our life, and we shall be proud to prove it towards all who are in fact loyal to their neighbors and to the Government in the hour of test. They are, most of them, as true and loyal Americans as if they had never known any other fealty or allegiance. They will be prompt to stand with us in rebuking and restraining the few who may be of a different mind and purpose. If there should be disloyalty, it will be dealt with with a firm hand of stern repression; but, if it lifts its head at all, it will lift it only here and there and without countenance except from a lawless and malignant few.

It is a distressing and oppressive duty, Gentlemen of the Congress, which I have performed in thus addressing you. There are, it may be, many months of fiery trial and sacrifice ahead of us. It is a fearful thing to lead this great peaceful people into war, into the most terrible and disastrous of all wars, civilization itself seeming to be in the balance.

But the right is more precious than peace, and we shall fight for the things which we have always carried nearest our hearts,-for democracy, for the right of those who submit to authority to have a voice in their own Governments, for the rights and liberties of small nations, for a universal dominion of right by such a concert of free peoples as shall bring peace and safety to all nations and make the world itself at last free. To such a task we can dedicate our lives and our fortunes, everything that we are and everything that we have, with the pride of those who know that the day has come when America is privileged to spend her blood and her might for the principles that gave her birth and happiness and the peace which she has treasured. God helping her, she can do no other. 


\section{Appendix( 2)}

\section{Franklin D. Roosevelt's War Message, Asking Congress to Declare War on Japan}

\section{Given on Monday, December 8, 1941}

Yesterday, December 7, 1941 - a date which will live in infamy - the United States of America was suddenly and deliberately attacked by naval and air forces of the Empire of Japan.

The United States was at peace with that nation and, at the solicitation of Japan, was still in conversation with its Government and its Emperor looking toward the maintenance of peace in the Pacific.

Indeed, one hour after Japanese air squadrons had commenced bombing Oahu, the Japanese Ambassador to the United States and his colleague delivered to the Secretary of State a formal reply to a recent American message. While this reply stated that it seemed useless to continue the existing diplomatic negotiations, it contained no threat or hint of war or armed attack.

It will be recorded that the distance of Hawaii from Japan makes it obvious that the attack was deliberately planned many days or even weeks ago. During the intervening time, the Japanese Government has deliberately sought to deceive the United States by false statements and expressions of hope for continued peace. The attack yesterday on the Hawaiian Islands has caused severe damage to American naval and military forces. Very many American lives have been lost. In addition, American ships have been reported torpedoed on the high seas between San Francisco and Honolulu.

Yesterday the Japanese Government also launched an attack against Malaya.

Last night Japanese forces attacked Hong Kong.

Last night Japanese forces attacked Guam.

Last night Japanese forces attacked the Philippine Islands.

Last night the Japanese attacked Wake Island.

This morning the Japanese attacked Midway Island.

Japan has, therefore, undertaken a surprise offensive extending throughout the Pacific area. The facts of yesterday speak for themselves. The people of the United States have already formed their opinions and well understand the implications to the very life and safety of our nation.

As Commander in Chief of the army and navy I have directed that all measures be taken for our defense.

Always will we remember the character of the onslaught against us.

No matter how long it may take us to overcome this premeditated invasion, the American people in their righteous might will win through to absolute victory. I believe I interpret the will of the Congress and of the people when I assert that we will not only defend ourselves to the uttermost but will make very certain that this form of treachery shall never endanger us again. 
Hostilities exist. There is no blinking at the fact that our people, our territory and our interests are in grave danger.

With confidence in our armed forces-with the unbounding determination of our people - we will gain the inevitable triumph-so help us God.

I ask that the Congress declare that since the unprovoked and dastardly attack by Japan on Sunday, December 7, a state of war has existed between the United States and the Japanese Empire.

\section{Appendix(3)}

\section{President George Bush Announcing War Agains Iraq}

On August 2, 1990, tanks and soldiers from Iraq crossed the border into neighboring Kuwait and seized the tiny, oil-rich nation. Iraqi troops then began massing along the border of Saudi Arabia.

Within days, American troops were sent to Saudi Arabia in Operation Desert Shield, protecting Saudi Arabia from possible attack. On August 6th, the United Nations Security Council imposed a trade embargo and financial sanctions against Iraq and authorized the use of force by naval forces in the Persian Gulf to prevent any violations. President George Bush addressed a joint session of Congress a few weeks later and stated the U.S. could not allow Iraqi dictator Saddam Hussein to seize control of vital oil resources in the Middle East. President Bush then doubled the size of Allied forces in the region to 430,000 soldiers.

On November 29th, the U.N. Security Council authorized its member nations to use "all necessary means" to expel Iraqi troops from Kuwait if they did not withdraw by a deadline of January 15, 1991. President Bush then ordered more troops to the Gulf to pressure Saddam Hussein into evacuating Kuwait.

On January 9, 1991, Secretary of State James Baker met with Iraqi Foreign Minister Tariq Aziz in Geneva for several hours in a last ditch effort to avoid war. The meeting ended in an impasse with Baker finally announcing the talks had failed. Three days later, the House of Representatives voted 250-183 and the U.S. Senate voted 52-47 to authorized President Bush to use military force.

The January 15th deadline passed quietly, as the 545,000 Iraqi troops in and around Kuwait did not budge. By now 539,000 American troops were in the Gulf along with 270,000 Allied troops from more than two dozen nations, the largest assembly of land troops and air power since World War II.

On January 17th, at 2:45 a.m., Baghdad time (6:45 p.m., January 16 - Eastern time), Operation Desert Shield became Operation Desert Storm as U.S. and Allied jets conducted a major bombing raid against Iraqi air defenses, communications systems, chemical weapons facilities, tanks and artillery. The air raid on Baghdad was broadcast live to a global audience by CNN correspondents perched on a city rooftop.

This is the television speech President Bush gave shortly after the air attack had commenced.

Just 2 hours ago, allied air forces began an attack on military targets in Iraq and Kuwait. These attacks continue as I speak. Ground forces are not engaged.

This conflict started August 2nd when the dictator of Iraq invaded a small and helpless neighbor. Kuwait -- a member of the Arab League and a member of the United Nations -- was crushed; its people, brutalized. Five months ago, Saddam Hussein started this cruel war against Kuwait. Tonight, the battle has been joined. 
This military action, taken in accord with United Nations resolutions and with the consent of the United States Congress, follows months of constant and virtually endless diplomatic activity on the part of the United Nations, the United States, and many, many other countries. Arab leaders sought what became known as an Arab solution, only to conclude that Saddam Hussein was unwilling to leave Kuwait. Others traveled to Baghdad in a variety of efforts to restore peace and justice. Our Secretary of State, James Baker, held an historic meeting in Geneva, only to be totally rebuffed. This past weekend, in a last-ditch effort, the Secretary-General of the United Nations went to the Middle East with peace in his heart -- his second such mission. And he came back from Baghdad with no progress at all in getting Saddam Hussein to withdraw from Kuwait.

Now the 28 countries with forces in the Gulf area have exhausted all reasonable efforts to reach a peaceful resolution -- have no choice but to drive Saddam from Kuwait by force. We will not fail.

As I report to you, air attacks are underway against military targets in Iraq. We are determined to knock out Saddam Hussein's nuclear bomb potential. We will also destroy his chemical weapons facilities. Much of Saddam's artillery and tanks will be destroyed. Our operations are designed to best protect the lives of all the coalition forces by targeting Saddam's vast military arsenal. Initial reports from General Schwarzkopf are that our operations are proceeding according to plan.

Our objectives are clear: Saddam Hussein's forces will leave Kuwait. The legitimate government of Kuwait will be restored to its rightful place, and Kuwait will once again be free. Iraq will eventually comply with all relevant United Nations resolutions, and then, when peace is restored, it is our hope that Iraq will live as a peaceful and cooperative member of the family of nations, thus enhancing the security and stability of the Gulf.

Some may ask: Why act now? Why not wait? The answer is clear: The world could wait no longer. Sanctions, though having some effect, showed no signs of accomplishing their objective. Sanctions were tried for well over 5 months, and we and our allies concluded that sanctions alone would not force Saddam from Kuwait.

While the world waited, Saddam Hussein systematically raped, pillaged, and plundered a tiny nation, no threat to his own. He subjected the people of Kuwait to unspeakable atrocities -- and among those maimed and murdered, innocent children.

While the world waited, Saddam sought to add to the chemical weapons arsenal he now possesses, an infinitely more dangerous weapon of mass destruction -- a nuclear weapon. And while the world waited, while the world talked peace and withdrawal, Saddam Hussein dug in and moved massive forces into Kuwait.

While the world waited, while Saddam stalled, more damage was being done to the fragile economies of the Third World, emerging democracies of Eastern Europe, to the entire world, including to our own economy.

The United States, together with the United Nations, exhausted every means at our disposal to bring this crisis to a peaceful end. However, Saddam clearly felt that by stalling and threatening and defying the United Nations, he could weaken the forces arrayed against him.

While the world waited, Saddam Hussein met every overture of peace with open contempt. While the world prayed for peace, Saddam prepared for war.

I had hoped that when the United States Congress, in historic debate, took its resolute action, Saddam would realize he could not prevail and would move out of Kuwait in 
accord with the United Nation resolutions. He did not do that. Instead, he remained intransigent, certain that time was on his side.

Saddam was warned over and over again to comply with the will of the United Nations: Leave Kuwait, or be driven out. Saddam has arrogantly rejected all warnings. Instead, he tried to make this a dispute between Iraq and the United States of American.

Well, he failed. Tonight, 28 nations -- countries from 5 continents, Europe and Asia, Africa, and the Arab League -- have forces in the Gulf area standing shoulder to shoulder against Saddam Hussein. These countries had hoped the use of force could be avoided. Regrettably, we now believe that only force will make him leave.

Prior to ordering our forces into battle, I instructed our military commanders to take every necessary step to prevail as quickly as possible, and with the greatest degree of protection possible for American and allied service men and women. I've told the American people before that this will not be another Vietnam, and I repeat this here tonight. Our troops will have the best possible support in the entire world, and they will not be asked to fight with one hand tied behind their back. I'm hopeful that this fighting will not go on for long and that casualties will be held to an absolute minimum.

This is an historic moment. We have in this past year made great progress in ending the long era of conflict and cold war. We have before us the opportunity to forge for ourselves and for future generations a new world order -- a world where the rule of law, not the law of the jungle, governs the conduct of nations. When we are successful -- and we will be -- we have a real chance at this new world order, an order in which a credible United Nations can use its peacekeeping role to fulfill the promise and vision of the U.N.'s founders.

We have no argument with the people of Iraq. Indeed, for the innocents caught in this conflict, I pray for their safety. Our goal is not the conquest of Iraq. It is the liberation of Kuwait. It is my hope that somehow the Iraqi people can, even now, convince their dictator that he must lay down his arms, leave Kuwait, and let Iraq itself rejoin the family of peace-loving nations.

Thomas Paine wrote many years ago: "These are the times that try men's souls." Those well-known words are so very true today. But even as planes of the multinational forces attack Iraq, I prefer to think of peace, not war. I am convinced not only that we will prevail but that out of the horror of combat will come the recognition that no nation can stand against a world united, no nation will be permitted to brutally assault its neighbor. No President can easily commit our sons and daughters to war. They are the Nation's finest. Ours is an all-volunteer force, magnificently trained, highly motivated. The troops know why they're there. And listen to what they say, for they've said it better than any President or Prime Minister ever could.

Listen to Hollywood Huddleston, Marine lance corporal. He says, "Let's free these people, so we can go home and be free again." And he's right. The terrible crimes and tortures committed by Saddam's henchmen against the innocent people of Kuwait are an affront to mankind and a challenge to the freedom of all.

Listen to one of our great officers out there, Marine Lieutenant General Walter Boomer. He said: "There are things worth fighting for. A world in which brutality and lawlessness are allowed to go unchecked isn't the kind of world we're going to want to live in."

Listen to Master Sergeant J.P. Kendall of the 82nd Airborne: "We're here for more than just the price of a gallon of gas. What we're doing is going to chart the future of the 
world for the next 100 years. It's better to deal with this guy now than 5 years from now."

And finally, we should all sit up and listen to Jackie Jones, an Army lieutenant, when she says, "If we let him get away with this, who knows what's going to be next?"

I have called upon Hollywood and Walter and J.P. and Jackie and all their courageous comrades-in-arms to do what must be done. Tonight, America and the world are deeply grateful to them and to their families. And let me say to everyone listening or watching tonight: When the troops we've sent in finish their work, I am determined to bring them home as soon as possible.

Tonight, as our forces fight, they and their families are in our prayers. May God bless each and every one of them, and the coalition forces at our side in the Gulf, and may $\mathrm{He}$ continue to bless our nation, the United States of America.

President George Bush - January 16, 1991

\section{الافتراض الحقيقي في خطابات الحرب الرئاسية الأمريكية: منظور التتاولي}

هذه الدراسة تعرض عملنا في المنظور التداولي للافتزاض الحقيقي للخطابات الحربية الرئاسية الأمريكية. الاهتمام الرئيسي لهذا العمل هو تسليط الضوء على أهمية "الو اقعية "في الخطابات المختارة ودورها في توصيل

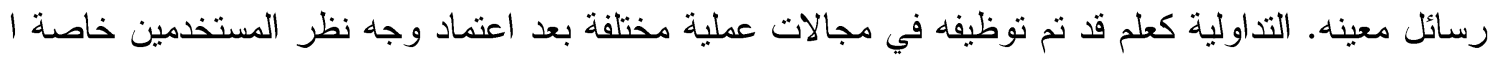
لأهداف والأغر اض المراد إنجازها. الافتر اض هو أحد المواضيع الأساسية في علم التداولية، لما له من أهمية

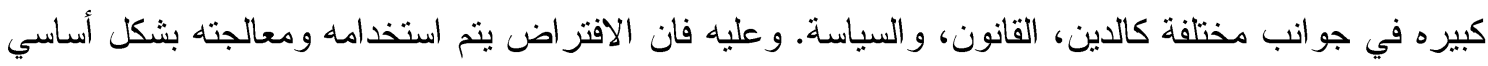

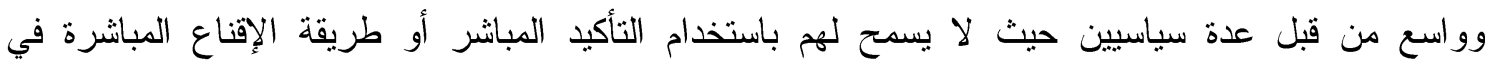

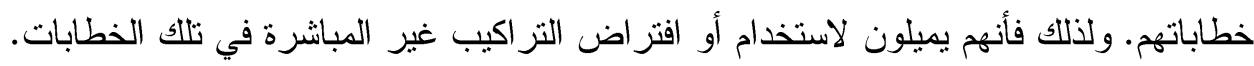
وبما أن الافتراض هو من المواضيع الهامة واسعة الانتشار والاستخدام الغير معلن، لذلك فإن السياسيين يرومون إلى استخدام الافتراض الحقيقي مرارا وتكرارا، خاصة في مسألة إعلان الحرب. في الجزء الأول الأول تتتاول الدراسة مصطلح الافتزاض الحقيقي ووجهة النظر العامة لهذه الظاهرة متعلقا بالواقعية والتزاكيب الحقيقة. إما الجزء الثاني فهو يتتاول السياسة ولغتها، و الجزء الأخير مكرس للجانب العملي و الذي من خلاله يتم تحليل الخطابات الحربية للرئاسة الأمريكية. 